\title{
"Obesity in the City" - Urbanization and rising obesity rates from the viewpoint of human biology and public health
}

\author{
Sylvia Kirchengast ${ }^{1} \mathbb{0} \cdot$ Dominik Hagmann $^{1}$ \\ 1 University of Vienna, Department of Evolutionary Anthropology, Djerassiplatz 1, A-1030 Vienna, Austria
}

\section{Citation:}

Kirchengast, S., Hagmann, D. ( 2021 ), "Obesity in the City", Human Biology and Public Health 2. https://doi.org/10.52905/hbph.v2.11.

Received: 2020-12-25

Accepted: 2021-04-09

Published: 2021-12-23

\section{Copyright:}

This is an open access article distributed under the terms of the Creative Commons Attribution License which permits unrestricted use, distribution, and reproduction in any medium, provided the original author and source are credited.

\section{Conflict of Interest:}

There are no conflicts of interest.

\section{Correspondence to:}

Sylvia Kirchengast

email: sylvia.kirchengast@univie.ac.at

\section{Keywords:}

childhood obesity, spatial differences, Vienna, gender

\begin{abstract}
In 2007, for the first time worldwide, more people lived in urban conurbations than in rural settlement structures. This advancing urbanization has dramatically altered the living situation, the use of space, as well as human behavior along with the health situation and disease burden. This process began in Europe as early as the $19^{\text {th }}$ century, while developing and emerging countries in particular are currently experiencing an increase in urbanization. The burden of disease is clearly altered by living in a confined space, by environmental pollution in urban areas, the impossibility of producing food oneself, and being lost in an anonymous crowd. Obesogenic environments represent a special problem in urban areas. A lack of physical activity, adverse dietary habits, and stressful and unsafe neighborhoods increase the risk of becoming overweight and obese in urban centers. Recently, modernization in rural areas and an adaptation to urban habits there increase the obesity rates in rural areas in high-income as well as low- and middle-income countries, too. Within cities, marked spatial differences in the prevalence of overweight and obesity occur. In Vienna, Austria, overweight and obesity rates during childhood and adolescence differ markedly between the individual Viennese districts. Highest overweight and obesity rates occur in districts characterized by a low socio-economic status.
\end{abstract}

Take home message for students We are currently confronted with the greatest wave of urbanization in the history of Homo sapiens. Urbanization is not only associated with modernization and cities are not only economic and cultural centers and areas of inspiration. Urban centers are also associated with increased psychic and somatic stress, health risks and high rates of obesity. 


\section{Introduction}

We are currently living in a rapidly changing world. Climate change, transcontinental migration, population ageing, over-population, digitalization, globalization and urbanization represent important stress factors for Homo sapiens. They have a major impact not only on economic and social development, but some of those factors also influence biological traits such as growth and development along with health and disease patterns. This makes the above-mentioned parameters of particular interest for both human biology and public health studies.

The association between urbanization and obesity prevalence is steadily gaining importance due to current trends: Twelve years ago, in 2008, a twofold turning point was reached. On the one hand, in 2007, for the first time, more than $50 \%$ of the world's population lived in urban habitats; the prediction is that this trend will continue in the coming years and decades (United Nations 2015). On the other hand, in 2008, for the first time in the long history of Homo sapiens, the number of overweight and obese people on Earth exceeded the number of people who suffer from starvation and malnutrition (FAO 2008). The association between both trends, e.g. urbanization and rising obesity rates is the topic of this review. In detail, urban environments are discussed from the viewpoint of Evolutionary Anthropology, current urbanization rates and overweight/obesity rates are presented. Particular attention is paid to obesogenic environments and spatial differences of obesity rates among children and adolescents in Vienna, Austria.

\section{Obesity - a worldwide public health concern}

Without doubt, obesity represents one of the major worldwide public health challenges of the $21^{\text {st }}$ century (Chooi et al. 2019; Spinelli et al. 2019). Overweight and obesity is commonly defined as an excessive amount of adipose tissue. Among adults a body mass index (BMI) above $25.00 \mathrm{~kg} / \mathrm{m}^{2}$ is considered overweight, a BMI above $30.00 \mathrm{~kg} / \mathrm{m}^{2}$ is considered as obese (WHO 2000). Among children and adolescents' of the same age and sex, overweight is defined as a BMI at or above the $85^{\text {th }}$ percentile and below the $95^{\text {th }}$ percentile. Obesity is defined as a BMI at or above the 95th percentile for children and teens of the same age and sex (Aggarwal and Jain 2018).

Obesity is mainly seen as a very recent phenomenon because at the population level obesity was rare up to the 1950s (Brown 1991; Haslam 2007). In the second half of the $20^{\text {th }}$ century, however, obesity rates rose sharply in the high-income countries and later also in the emerging countries. Once considered a condition typical solely of affluent societies in the industrialized world, overweight and obesity rates are now fast growing in poor neighborhoods of high-income countries as well as in many middle- and low-income countries (WHO 2000; WHO 2010; Hossain et al. 2007; Pijl 2011; Chooi et al. 2019). Between 1975 and 2016, the world-wide prevalence of obesity nearly tripled (Blüher 2019). According to the World Health Organization (WHO), in 2016, more than 1.9 billion adults (18 years) were overweight $\left(\mathrm{BMI}>25.00 \mathrm{~kg} / \mathrm{m}^{2}\right)$; of these, 650 million adults were classified as obese. This means that $39 \%$ of the world's adult population were overweight, 13\% obese (Chooi et al. 2019; WHO 2020). Figure 1 presents overweight + obesity rates for adult males and females according to 


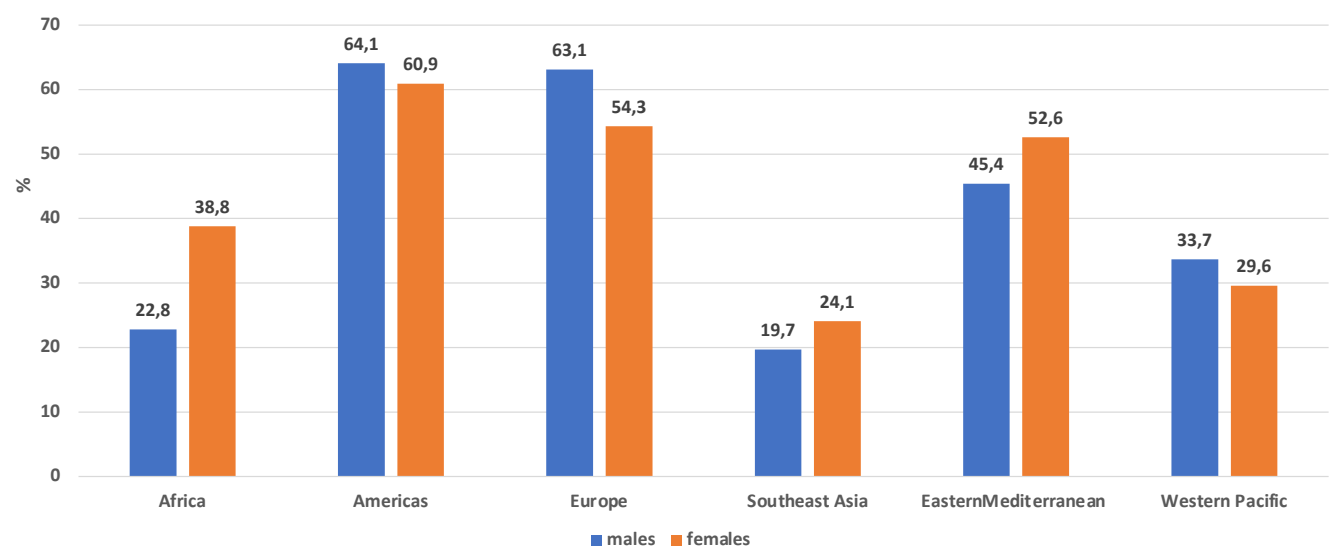

Figure 1 Overweight and obesity rates according to World regions according to the WHO (WHO 2020).

world regions. Lowest overweight and obesity rates are found for Southeast Asia and Africa. The highest rates are found for the Americas and Europe.

A special problem is the rising rates of overweight and obesity among children (Spinelli et al. 2019). In 2016, more than 340 million children and adolescents aged 5-19 years were overweight or obese worldwide. Furthermore, the prevalence of overweight and obesity among children younger than 5 years has increased dramatically. In 2019, about 38.2 million children under the age of 5 years were overweight or obese. This is true not only of high-income countries but also of middle- and low-income countries (WHO 2020). Currently, nearly half of the overweight or obese children younger than 5 years live in Asia. In Africa as well, however, the number of overweight children younger than 5 years has increased by nearly $24 \%$ since 2000 .

This high prevalence of excessive body weight worldwide is a matter of concern because obesity represents an important risk for premature mortality and morbidity
(Ford and Mokdad 2008; Wang et al. 2011). Furthermore, overweight and obesity are not merely individual health problems they also place an enormous economic burden on public health and social systems of governments. This makes the analysis of risk factors enhancing the risk of overweight and obesity ever more important.

From a physiological point of view, overweight and obesity are caused by an imbalance between energy intake and expenditure (Florentino 2002). On the one hand, this imbalance, is associated with genetic factors. There is no doubt, that obesity is complex heritable trait (Thaker 2017). Beside monogenic causes such as single gene mutations primarily located in the leptin- melanocortin pathway, polygenic obesity is caused by a cumulative contribution of a large number of genes (Thaker 2017). Currently it is assumed that the genetic component may contribute to $40-70 \%$ of obesity (Chiurazzi et al. 2020). On the other hand, there is a strong environmental component, which may enhance the risk of obesity. The main environmental reason 
for rising obesity rates worldwide is the globalization of increasingly obesogenic environments, which are mainly characterized by rapid urbanization associated with the mechanization of jobs, improved transportation services, the availability of food of high energy density, and reduced physical activity (Popkin and Udry 1998; Popkin 2001; Popkin 2003; Popkin and Gordon-Larsen 2004; Poston and Foreyt 1999; Ulijaszek 2007; Ulijaszek and Lofink 2006).

\section{Urbanization - a problem of definition}

Urbanization is apparently related to rising obesity rates worldwide. Before we start to discuss the phenomenon urbanization and its associations with parameters of human biology, such as growth patterns, but also parameters of public health, in particular obesity rates, we have to define the terms urbanization, urban environments, urban centers and cities. Urbanization describes the process by which large numbers of people become permanently concentrated in relatively small areas, forming urban habitats or cities. To date, no uniform definition of the terms city or urban centers exists. A city is commonly defined as a large human settlement, the term "city" however, has different meanings around the world. Some definitions classify human settlements with more than 250,000 inhabitants as cities, while and in some places the settlement can be very small indeed. A town in contrast, is defined as a settlement that is larger than villages, but smaller than cities. An important trait of cities is, that the inhabitants work primarily on non-agricultural tasks (Caves 2005). Even the United Nations (UN) uses regional definitions, which vary considerably from state to state. For instance, the
United States defines an urban place as any locality, where more than 2,500 People live. In contrast, in Peru an urban place is any locality with 100 or more dwellings (Duignan 2019). In Japan, a city is defined as a shi with a minimum of 50,000 inhabitants, while Sweden or Denmark set the threshold at only 200 inhabitants. The most frequently used thresholds for the definition "urban" are 2,000 to 5,000 inhabitants. The European Commission defined urban centers as areas with more than 50000 inhabitants plus a population density of at least 1500 people per square kilometer $\left(\mathrm{km}^{2}\right)$. Urban clusters are defined as areas with a minimum of 5,000 inhabitants plus a population density of at least 300 people per square kilometer $\left(\mathrm{km}^{2}\right)$. Every location with less than 5,000 inhabitants is considered as rural. Therefore, the degree of urbanization differs depending on the definition. According to the definitions of the European commission only 15\% of the world population lived in rural areas, while 52\% lived in urban centers and 33\% in urban clusters in 2016. As presented in Figure 2, major differences in the percentage of urbanization between the UN definition and the European commission definition occur for Africa and Asia. These differences in the definitions of urban areas may contribute to the inconsistent findings of the associations between obesity and urbanization.

\section{Urbanization from the viewpoint of evolutionary anthropology}

From the perspective of evolutionary anthropology, urbanization or the trend towards urban forms of settlement is a very recent phenomenon. More than 2 million years have passed since the first appearance of the genus Homo (Antón and Snodgrass 2012). Anatomically modern Homo sapiens has been recorded for more than 


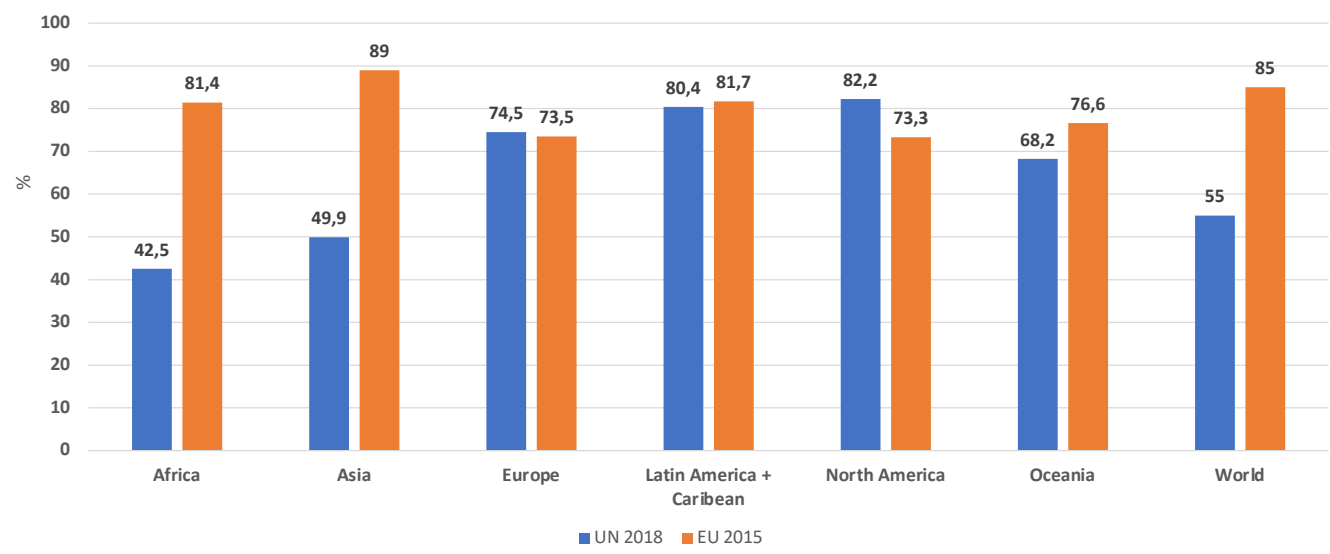

Figure 2 Urbanization world-wide in 2015 und 2018 - a comparison between the definition of United Nations Organization and the definition of the European commission.

150,000 years (Stringer 2016), but the first urban forms of life appeared only around 10,000 years ago (Davis 1955; Wilkinson et al. 2014). The environment in which the evolution to modern humans took place, the so-called "environment of evolutionary adaptedness" (EEA) (Bowlby 1969), therefore differed completely from current urban environments. Our ancestors followed a hunter and gatherer lifestyle characterized by high mobility in small groups without permanent homes. Group size seldom exceeded 100 people (Dunbar 1993), and the daily routine was determined by the search for food and water. Living in crowded cities, overeating and lack of physical activity as a population problem were equally unknown as the holding of domesticated animals with the exception of dogs (Cohen et al. 2013).

As a result of the Neolithic transition, the earliest settlements known as "cities" such as Jericho, which is located in what is now the West Bank, or Catalhöyük in recent Turkey - emerged around 10,000 years ago (Davis 1955; Mumford 1961; Maher et al. 2012; Wilkinson et al. 2014). The number of inhabitants did not exceed 3,000. According to the current definition, both cities would correspond more to larger villages. A higher number of inhabitants could not have been supported due to food supply problems, because the technical possibilities in the Neolithic would not have enabled feeding a larger population in a limited space. Technical innovations such as irrigation systems, the use of the plow, or metallurgy made it possible to increase production and promoted larger settlements that deserve the name city and comprised up to 15,000 inhabitants. Such cities emerged in Egypt, Mesopotamia, China and India from 3,000 BC (Davis 1955). In the $2^{\text {nd }}$ millennium $B C$, cities such as Theben were assumed to already have over 100,000 inhabitants. Nonetheless, it was difficult to cross the 200,000 inhabitants limit, as 50 to 90 farmers were still required to produce food for one city dweller (Davis 1955; Cohen et al. 2013). In 
the $5^{\text {th }}$ century BC, cities with over 100,000 inhabitants such as Athens, Carthage and Syracuse emerged in the Mediterranean region. Rome was the first metropolis in history. Here, improved agricultural technology, efficient traffic routes and highly developed administration enabled the city dwellers to be fully supplied (Mumford 1961). On the other hand, a high incidence of infectious diseases in urban habitats of the Roman Empire was reported for the $1^{\text {st }}$ century AD by Pliny the Elder in his Historia Naturalis and by von Galen in the $2^{\text {nd }}$ century AD (Scheidl 2010). With the exception of Constantinople, ancient Rome represented the only megacity until London became the first metropolis of modern times in the $19^{\text {th }}$ century. Focusing on Europe, urban ways of life established themselves from the High Medieval times, but the population remained comparatively low. In the $14^{\text {th }}$ century, Florence had around 90,000 inhabitants, London around 30,000. The first major urbanization spurt came in the late $18^{\text {th }}$ and especially in the $19^{\text {th }}$ century in the course of the Industrial Revolution (Schott 2014). Starting in England, poverty drove an increasing number of people from rural areas into the emerging industrial cities, thus triggering urbanization. Around 1800 there were fewer than 50 cities with 100,000 or more inhabitants worldwide, with only $1.7 \%$ of the world population living in cities with more than 100,000 inhabitants, and $2.4 \%$ in cities with more than 20,000. In 1900 these values were $5.5 \%$ and $9.2 \%$, in 1950 $13.1 \%$ and $20.9 \%$, respectively (Davis 1955). In the last few decades this urbanization process has reached the so-called emerging and developing countries and assumed unimagined proportions.

Currently, we are confronted with the greatest wave of urbanization in human history. By 2030, 5 billion people are expected to live in urban conurbations and practice an urban lifestyle. Urbanization is the result of the growth of existing cities, primarily through rural-urban migration, the so-called physical urbanization. In turn, it also alters the behavior of residents of rural regions in what is termed functional urbanization (Mumford 1961). This increase in the urban population will primarily affect developing and emerging countries, which currently have an urbanization rate of around $48 \%$, whereas in the industrialized countries the proportion of the urban population exceeded the $70 \%$ mark in 1990. In particular, this development will present African and Asian countries with high population growth with unexpected challenges in economic, ecological, but also social and health policy terms (Leon 2008; Bork et al. 2009).

The trend is towards megacities with more than 5 or even more than 10 million inhabitants, depending on the definition, as well as polycentric agglomerations such as the Pearl River Delta in southern China (Bork et al. 2009). There are currently more than 50 megacities worldwide, more than two-thirds of which are in developing and emerging countries and are characterized by barely manageable or controllable development. Examples include Istanbul (14 million), Lagos (10 million), Sao Paolo (21 million), Cairo (17 million) Mexico City (20 million), Kolkatta (14 million) or Mumbay (18.4 million), in which the living conditions can often be described as catastrophic. This applies above all to the slum areas, which are primarily inhabited by rural-urban migrants. These urban agglomerations are characterized by overpopulation, environmental pollution, resource consumption, water scarcity, poor hygienic conditions (Qian et al. 2001; Canfield et al. 2003; Schell 2014; Schell 2010; Jaffar et al. 2017), social conflicts and the resulting psychological stress (Calhoun 1962; Dunbar 1993; Ramsden 2009; Logan and Jacka 2014; Miller 2016) - all leading to increased disease risks. At the same time, 
however, urban centers are characterized by better educational and work opportunities as well as better access to health facilities (Bork et al. 2009).

\section{Urban environments and parameters of human biology}

Body height and growth patterns are widely used as biological welfare measurements and public health indicators. Growth patterns and, ultimately, body height are influenced not only by genetic disposition but also by environmental factors such as resource availability, climate, nutrition, socioeconomic conditions as well as social status and psychosocial factors (Bogin 2021; Schell et al. 2009). Furthermore, growth and body height are associated with individual health status, but also with life circumstances and social and economic conditions on the population level (Komlos 1994; Komlos 1998). Numerous studies have examined the effects of the urban environment on growth patterns during the subadult phase, body height and health (Tanner and Eveleth 1976; Komlos 1986; Rona 2000; Martínez-Carrión and MorenoLázaro 2007). Growth inequalities and differences in body height between inhabitants of urban and rural areas are of special interest. Up to the Industrial Revolution, the differences between rural and urban populations in Europe remained insignificant (Kaupová et al. 2013). Thereafter, however, dramatic differences were reported in body height between rural and urban populations, with a clear urban height penalty (Zehetmayer 2013). The body height of rural populations tended to exceed that of urban ones. This urban penalty was mainly due to the low standard of sanitation, high population density, high disease load and higher food prices in towns and emerging Industrial cities (Martínez-Carrión and Moreno-Lázaro 2007). Such adverse urban environmental conditions impaired growth patterns and ultimately led to a shorter stature among the urban population. Similar trends were observed for the United States: during the $19^{\text {th }}$ and early $20^{\text {th }}$ century, body heights and weights were lower in urban versus rural areas (Carson 2020). By the early $20^{\text {th }}$ century, however, this trend was almost universally reversed. Mortality rates fell and stature height increased due to improved living conditions in European cities, including a reduction of child labor, purification of the water supply, canalization and sanitation, along with advances in the food supply, vaccination programs, medical care and higher incomes (Schonfield et al. 1991; Komlos 1998). The body height of urban populations exceeded those of their rural counterparts. Currently, rural-urban differences in body height have diminished in most high-income countries. In middleand low-income countries, however, such differences still occur. In Venezuela, urban children were taller and heavier than their rural counterparts. These differences were evident after age 2 and puberty in boys and girls, and persisted into adulthood (Blanco et al. 1992). Major growth inequalities between urban and rural areas have been reported in China over the past 40 years. Economic development and urbanization decreased these differences in body height between children from rural and urban areas, but new public health challenges emerged, in particular rising obesity rates (Zong et al. 2017; Hu et al. 2020).

\section{Urban environments as health risks}

Urbanization and urban environments are associated with various health risks. The high population density represents ideal conditions for the spread of infectious diseases. This is because enough hosts live in a confined space, enabling transmission through direct and indirect contact. At the 
same time, high population densities also mean a problem for the supply of pure drinking water, sufficient food, and waste disposal. The combination of dense populations and poor hygiene predestines the occurrence of infectious diseases. These patterns of infection incidence were also typical during plague pandemics several centuries ago (Roberts and Lewis 2002), but even today, infectious diseases were more common in urban areas. Beyond wellknown infectious diseases such as tuberculosis and influenza, new infectious diseases such as HIV/AIDS, SARs, influenza, and COVID-19 also find an ideal biotope in overpopulated megacities (Bork et al. 2009; Neiderud 2015).

Rapid urbanization has a clear impact on morbidity and mortality patterns (Vlahov et al. 2007; Leon 2008). This is unsurprising because changes in life style and living conditions have always led to changes in the burden of illness. The negative impact of urbanization on health started with the Neolithic transition and the associated first epidemiological transition about 10,000 years ago (Armelagos et al. 2005), when the transition from an appropriative to a productive subsistence forced people to give up a mobile way of life as hunters and gatherers and to become sedentary farmers. The domestication of plants and animals, life in village and later urban communities, and the changed food spectrum drastically altered the burden of disease and reduced life expectancy. Although the main health problems of these early stages of urbanization seem to be the rise of infectious diseases caused by poor hygienic conditions and new emerging zoonoses, nutrition associated health problems gain in importance. For the first time a double burden of malnutrition may be assumed. On the one hand, the more one-sided and, due to crop failures, poor nutrition led to starvation and malnutrition, on the other hand, reduced physical activity and diets rich in carbohydrates and fat from domesticated animals may increase the risk of overweight for the first time in human history (Cohen et al. 2013).

Malnutrition was still an important health hazard during the second epidemiological transition, which took place during the Industrial Revolution in the late $18^{\text {th }}$ and early $19^{\text {th }}$ centuries. There, the dramatic increase in population combined with rapid urbanization and industrialization led to a dramatic deterioration in the health situation in the emerging industrial cities (Roberts 2016). Beside the adverse effects of environmental pollution from factories, overwork from toiling under inhumane conditions in industrial plants, and catastrophic living and hygiene conditions on health and disease patterns, malnutrition and associated diseases became an eminent problem. People in urban environments were no longer able to produce their food by themselves, they had to buy it and spend a lot of money to get enough food. Between 1780 and 1850 families in British industrialized cities had to spend about $75 \%$ of their income on flood (Griffin 2018). Consequently, malnutrition and starvation were quite common. On the other hand, since the industrial revolution refined grains and sugar have been consumed in huge quantities, resulting in a frequent intake of high-glycemic index carbohydrates, which are digested and absorbed quickly (Matthews 2012). The double burden of malnutrition was omnipresent in the urban environment during the Industrial Revolution.

The third epidemiological transition is currently taking place. The considerably improved living conditions in the industrialized countries, combined with the enormous advances in disease control and prevention, have led to completely new disease patterns in the last few decades. Improvements in medicine, hygiene and vaccination programs pushed back infectious 
diseases. This increased life expectancy, but the accompanying hyperalimentation and rising obesity rates promoted so-called diseases of civilization or non-communicable diseases such as cardiovascular diseases, metabolic disorders and cancer (Pollard 2008).

\section{Urban environment and obesity}

Obesity rates are increasing worldwide, currently more rapidly in rural than in urban areas (NCD Risk Factor Collaboration 2019; Mahase 2019). This increase in rural areas seems confusing at a first glance because obesogenic environments are mainly found in urban areas. One possible explanation may be, that rising obesity rates in poor rural areas reflect nutrition and developmental assistance programs in lowand middle-income countries, but also the expansion of an obesogenic environment from urban areas to rural ones (Mou et al. 2013; Paciorek et al. 2013; Khan and Kraemer 2014). Interestingly, the steadily increasing urbanization rates unfortunately did not help reduce obesity rates in urban settlements. Even there, rising rates of overweight and obesity represent a public health challenge. Another possible explanation for this interesting trend of rising obesity rates in rural areas may be the different definitions of rural and urban areas, which are used in different countries. As pointed out above, there is no generally accepted definition what is a village, a city, a town or what is rural, what is urban.

Figure 3 presents a comparison of urbanization rate and overweight + obesity rate according to the World Bank income regions. This comparison shows, that the urbanization rate as well as the overweight obesity rate among adults drops down with decreasing income. The lower the urbanization rate, the lower is the overweight+ obesity rate.
In order to discuss the effects of urban environment on overweight and obesity rates, it is necessary to define an obesogenic environment. According to Swinburn et al. 1999, an "obesogenic environment" is "an environment that promotes gaining weight and one that is not conducive to weight loss" within the home or workplace. Thus, the obesogenic environment refers to one that helps, or contributes to, obesity. But what are the characteristics of such an environment? The main characteristics are conditions that reduce physical activity, a food environment that promotes the availability and accessibility of cheap food rich in fat and sugar, and social neighborhoods that are unsafe and stressful. Other typical obesogenic environments are low-density areas with segregated land use, low connectivity and a high dependence of car use, but also conditions which discourage walking, bicycling to schools or workplaces, or outdoor physical activity during leisure. Note, however, that such conditions can equally be found in nice middle-class suburban areas and in unsafe socioeconomically disadvantaged neighborhoods (Congdon 2019). Finally, a high density of fast food outlets, convenience stores offering processed energy-dense food, as well as a stressful social environment and unsafe neighborhood that address the hypothalamic-pituitary-adrenal axis and thus increase stress hormone levels are typical of obesogenic environments (Congdon 2019).

For a long time, this type of environment was interpreted as being typical of socioeconomically disadvantaged urban areas in high-income countries. Today, such environmental conditions are increasingly found low- and middle-income countries, in particular in rural areas which adopt these characteristics to interface with modernization and globalization processes.

Overweight, obesity and associated metabolic diseases are typical of the current third epidemiologic transition (Armela- 


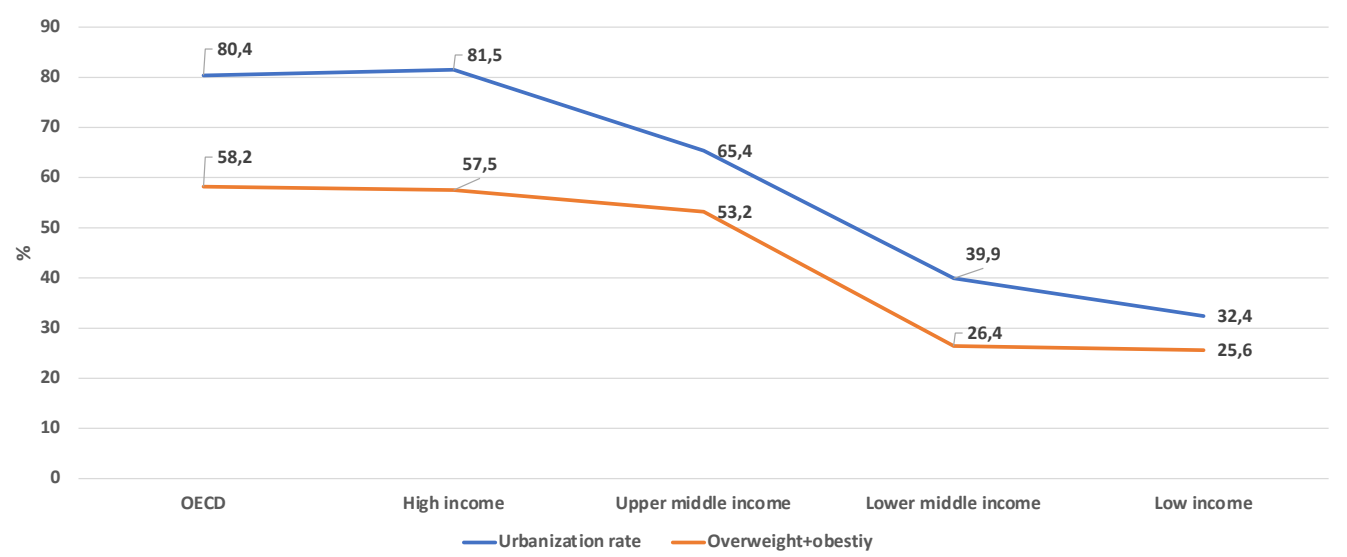

Figure 3 Overweight and obesity rates according to income regions according to the World Bank (Shekar and Popkin 2020).

gos et al. 2005; Barrett et al. 1998). Obesogenic environments are clearly the result of modernization processes, which started more than 50 years ago in high-income countries and now sprawl throughout the world. Technical advances and modernization of lifestyle result in a marked transition in human life. The daily energy effort to gather and prepare sufficient food is reduced to nearly zero because only few individuals work in food production. Mechanized transportation, sedentary jobs and labor-saving household technologies reduce physical activity too. At the same time, more than enough energy-dense food, mainly consisting of sugar and fat, is easily available (Popkin 2001; Popkin and Gordon-Larsen 2004; Lieberman 2006; Eaton and Konner 1985). Once a problem of the industrialized world, globalization, modernization and urbanization now promote obesogenic environments and enhance the risk of overweight and obesity in rural as well as urban areas of developing countries. These include Indonesia (Nurwanti et al. 2019), India (Ebrahim et al. 2011),
China (Dong et al. 2019; Shen et al. 2019), Guatemala (Groeneveld et al. 2007), or Peru (Antiporta et al. 2016; Najera et al. 2019). In developed countries, poor neighborhoods, low socioeconomic status and a background of migration are typical risk factors for overweight and obesity among urban children and adults (Timmermans et al. 2018; Ogden et al. 2018).

Today, in high-income countries such obesogenic environments are mainly found among lower socioeconomic groups, characterized by low incomes, low educational levels and living in a poor and unsafe neighborhood (Ball and Crawford 2005; Hook and Balistreri 2007; Faskunger et al. 2009; Wang and Beydoun 2007). These conditions are frequent in urban environments. In middle- and low-income countries, in contrast, this relationship is reversed. People of high socioeconomic status who underwent a rapid transition in nutritional habits and general life style are more likely to be obese. In societies of economic and nutritional transition, the paradox situation is that malnutrition and obesity rise 
in parallel (Chatterjee 2002). Moreover, numerous investigators have demonstrated that migrant status increases the risk of overweight or obesity. This is true of rural-urban migrants in low-income countries, of Hispanic immigrants in the United States (Kaplan et al. 2004), as well as of immigrants originating from Mediterranean countries or the Middle East in Central and Northern Europe (Brussaard et al. 2001; Kirchengast and Schober 2006; Misra and Ganda 2007; Wolin et al. 2009). Immigrant obesity is the result of rapid modernization and a fast transition into an obesogenic environment.

An especially dramatic stress factor is transnational rural-urban migration. On the one hand, urban conurbations are particularly attractive for migrants due to their mostly multicultural character but also due to the diverse work and educational opportunities. On the other hand, such transnational migration increases the risk of illness because migration and integration into a new cultural environment are stress factors per se. In addition, immigrants often have a lower social and socioeconomic status than the guest population and therefore live in cheaper and typically more polluted and disadvantaged residential areas (Gushulak and MacPherson 2006). Finally, a lower level of education and poor language skills impede access to medical facilities (Carballo et al. 1998). Migration from rural regions to an urban environment in another country therefore often represents a double stress situation. Less daily physical activity and the availability of cheap, sugar- and fat-rich food increase the risk of becoming obese. Thus, a significantly increased risk of obesity and associated diseases was documented for Turkish and Indian women who had migrated from rural regions in their home country to the city of Vienna (Kilaf and Kirchengast 2011; Kirchengast et al. 2012). The obesity prevalence among migrant women was significantly higher than that of women in their region of origin as well as of Viennese women without a migration background. The main reasons for this are probably changes in eating habits and a lack of exercise.

\section{Overweight and obesity in Austria}

Overweight and obesity rates are high in Austria. As presented in Figure 4, during the last 15 years about $40 \%$ of adult males and more than $25 \%$ of adult females were classified as overweight (BMI between 25.00 and $29.99 \mathrm{~kg} / \mathrm{m}^{2}$ ). Since 2006, the rates of obesity (BMI $\left.>30 \mathrm{~kg} / \mathrm{m}^{2}\right)$ increased among males from $12.4 \%$ in 2014 to $17.9 \%$ in 2019. Among adult females, obesity rates increased from $13 \%$ to $15 \%$ during the same period (Bundesanstalt Statistik Österreich 2019).

Furthermore, regional differences in the obesity prevalence are observable (Figure 5). The analysis of conscript data revealed lowest rates of overweight and obesity in the rural Western areas of Austria and the highest overweight and obesity rates for the more urbanized Eastern parts of Austria (Rami et al. 2004).

\section{Childhood overweight and obesity in Vienna, Austria}

A special problem represents the increasing rates of obesity and overweight among children and adolescents (Ebbeling et al. 2002; Kimm and Obarzanek 2002; Wang and Lobstein 2006; Lasserre et al. 2007; Han et al. 2010). On the one hand obesity during childhood and adolescence has long-term health consequences (Must et al. 


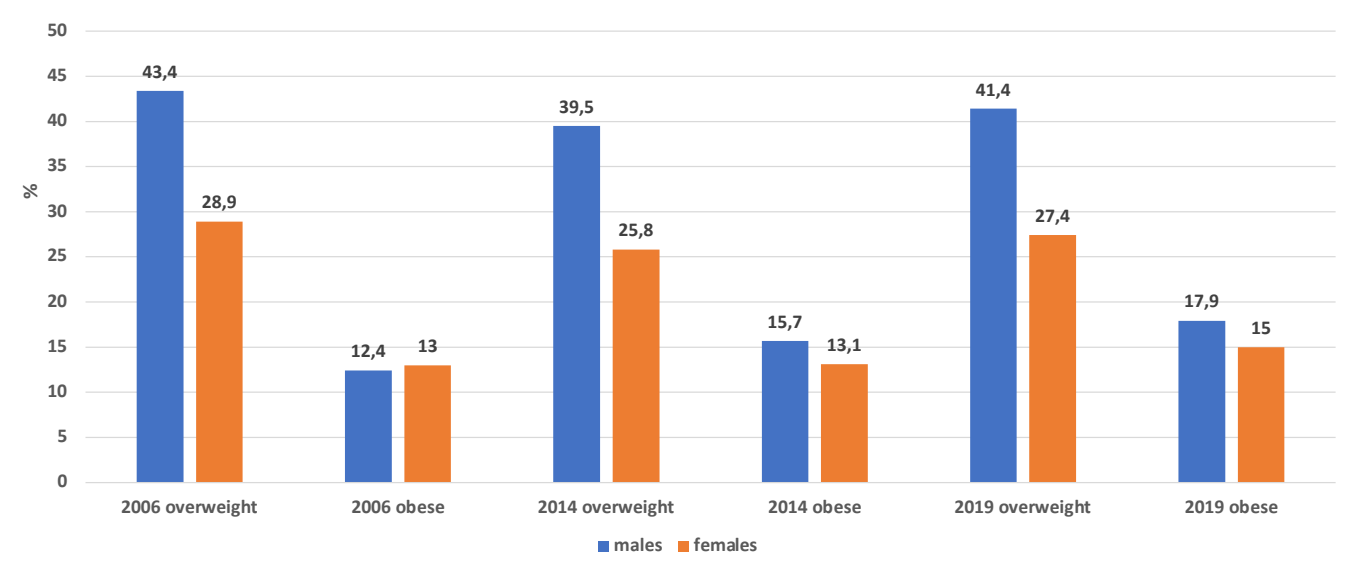

Figure 4 Overweight (BMI 25.00 to $29.99 \mathrm{~kg} / \mathrm{m}^{2}$ ) and obesity (BMI > $30.00 \mathrm{~kg} / \mathrm{m}^{2}$ ) among Austrian adults between 2006 and 2019 (Bundesanstalt Statistik Österreich 2019).

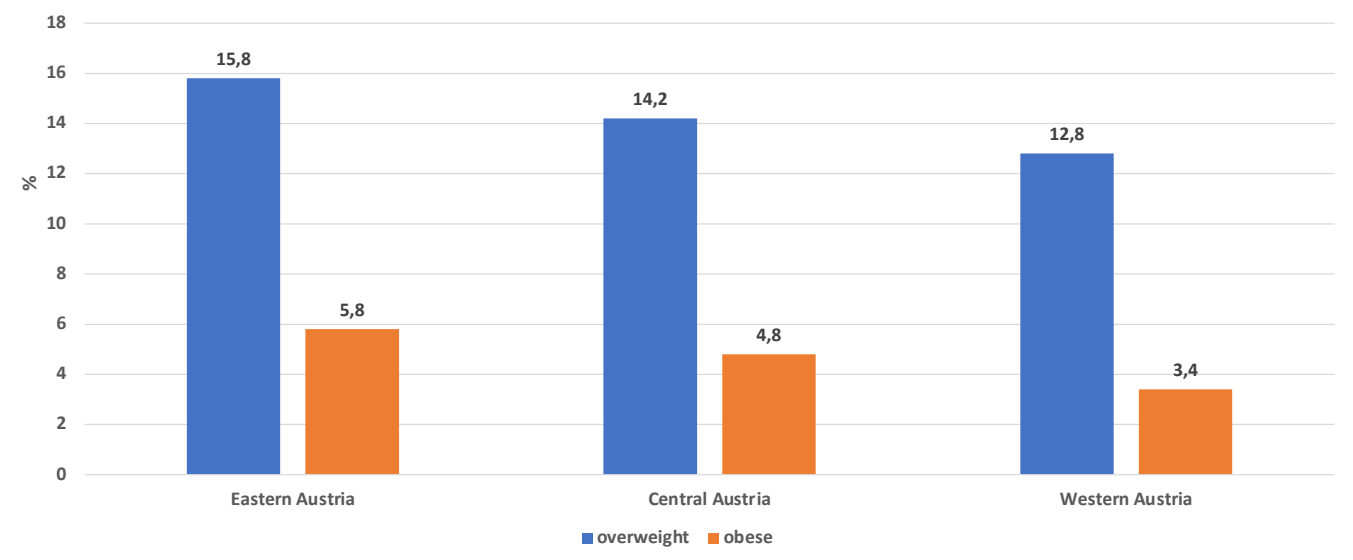

Figure 5 Overweight (BMI 25.00 to $29.99 \mathrm{~kg} / \mathrm{m} 2$ ) and obesity (BMI > $30.00 \mathrm{~kg} / \mathrm{m} 2$ ) among Austrian conscripts according to Austrian region (Rami et al. 2004).

1992; McGee 2005), on the other hand childhood obesity predicts individual and global economic problems (Withrow and Alter 2011). One risk factor for obesity among children but also adults is a low so- cioeconomic status (Gnavi et al. 2000; Haas et al. 2003; Lissner et al. 2016; Poulsen et al. 2018). Therefore, spatial disparities in the prevalence of overweight and obesity in 


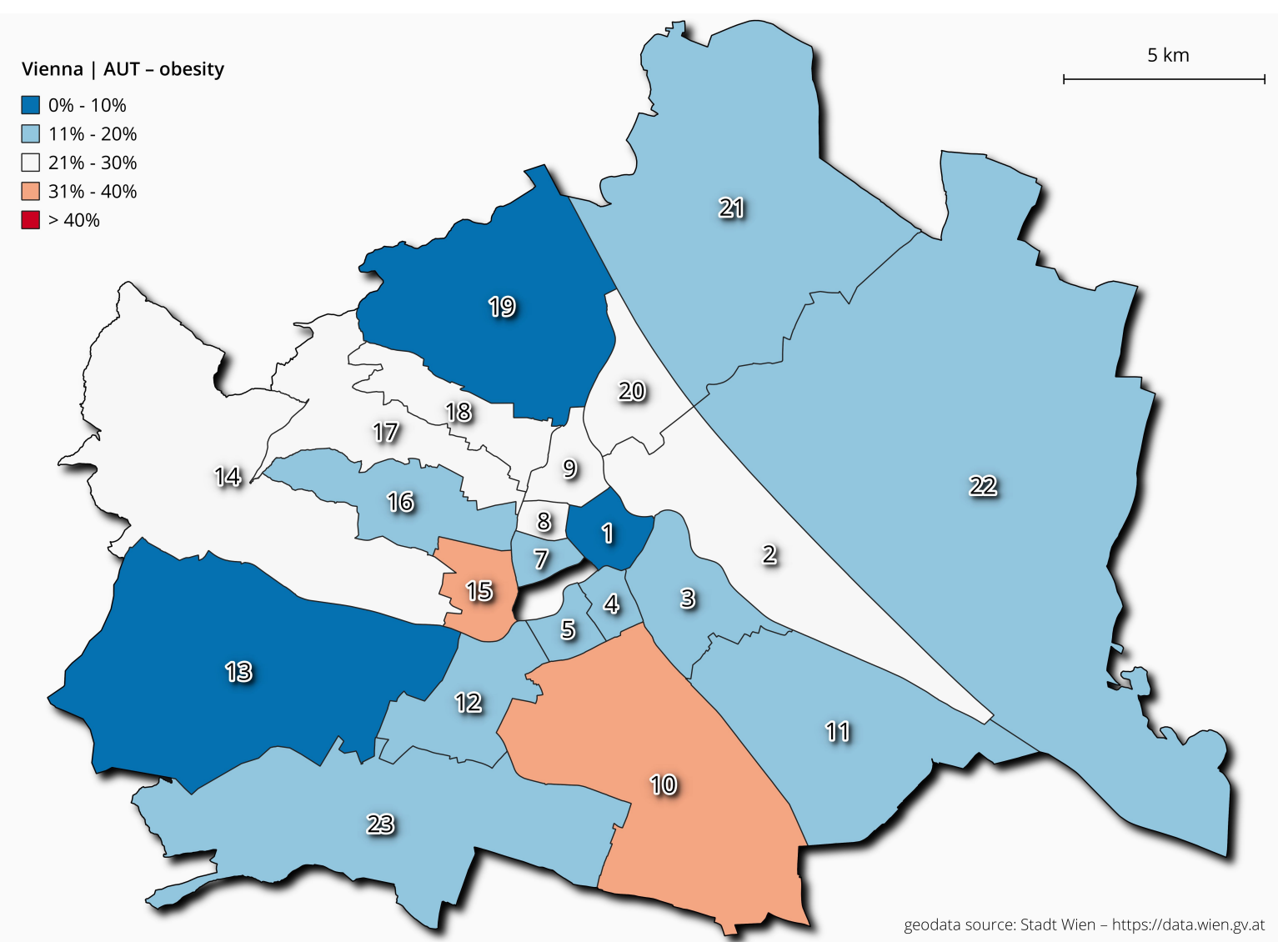

Figure 6 Overweight and obesity rates among 6-year-old children for each Viennese district.

urban centers can be found (Kirchengast and Hagmann 2021).

As noted above, advancing urbanization is also associated with characteristic disease risks, obesity being one example. Importantly, however, caution is advised against generalizations, considering the current urbanizing world. Urban centers or cities are not homogeneous environments. This also applies to the national and international comparison of cities; even within a city, the individual districts differ in their economic, social and ecological characteristics, and these are reflected in a regional variation of disease risks even within a city. In Vienna, for example, life expectancy varies considerably between the individual districts. In Vienna's upper-class districts such as the $13^{\text {th }}$ or $19^{\text {th }}$ districts, life expectancy is more than 7 years longer than in more disadvantaged areas such as the $15^{\text {th }}, 12^{\text {th }}$, $17^{\text {th }}$ or $20^{\text {th }}$ districts (Bachinger 2003; Bun- desanstalt Statistik Österreich 2019), although the spatial distance between the districts is quite small. These differences in life expectancy depend mainly on the economic and social characteristics of the respective district.

Equally, obesogenic environments differ between the individual districts. This is reflected in the high prevalence of obesity among children and adolescents in socially disadvantaged districts of Vienna (Kirchengast and Hagmann 2021). In our study we analyzed a medical record-based dataset which was provided by the Viennese school medical authority. Forty-four public secondary schools (two from each of the 23 districts of Vienna, with the exception of the sixth district) were randomly selected from the Viennese school authority. In Austria, it is obligatory that - beside medical data - the body height and body weight of all school children are collected 


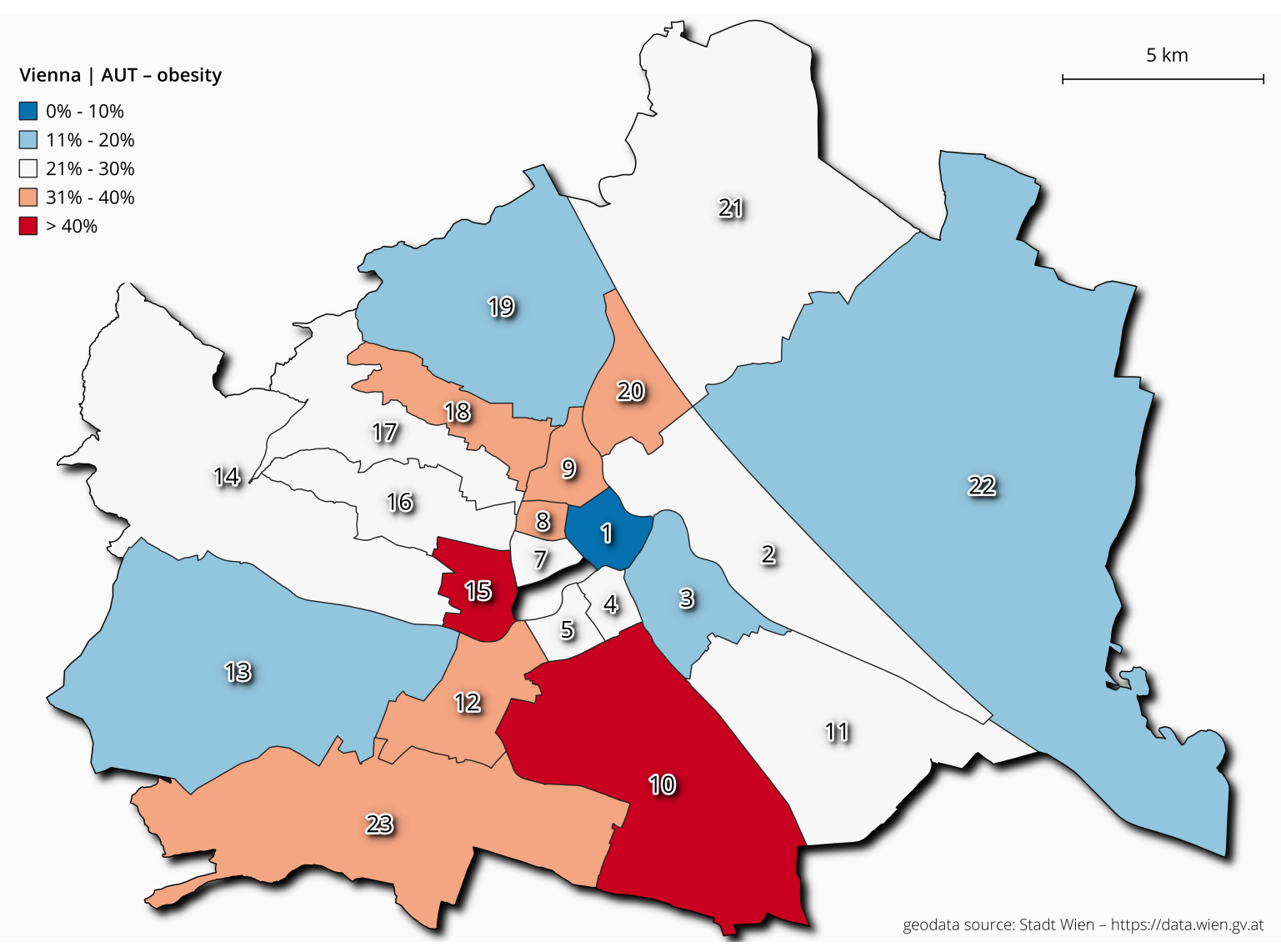

Figure 7 Overweight and obesity rates among 10-year-old children for each Viennese district.

by specially educated personnel of the medical school authority. The data file including all information on body heights and body weights are stored by the Viennese school medical office, to which we had access. We analysed the data of 2,006 boys and 1,840 girls. Weight status was classified according to the percentiles published by Kromeyer-Hausschild et al.(2001). These German charts are used because no validated Austrian charts exist. A BMI $\left(\mathrm{kg} / \mathrm{m}^{2}\right)$ above the sex and age specific $90^{\text {th }}$ percentile was defined as overweight, a BMI) above the age and sex specific $97^{\text {th }}$ percentile was defined as obese. In the present study, we included all BMIs above the $90^{\text {th }}$ percentile in one group, comprising obesity and overweight. In order to compare the overweight and obesity rates between the individual Viennese districts, we performed a spatial data analysis. We exported a data query of classified percent shares for every Viennese district (except for the $6^{\text {th }}$ district, where no data was available for this study) from IBM SPSS in XLSX file format. For the spatial data analysis, we loaded a structured table containing the anthropological data and ESRI Shapefiles providing spatial information on Vienna (Stadt Wien 2011; Stadt Wien 2012) into the free and open-source geographic information system software QGIS. As a coordinate reference system, we used EPSG:31256 MGI / Austria GK East. For geostatistic analysis and mapping, we applied 'natural breaks' after Jenks (Jenks and Caspall 1971; Smith et al. 2020) to cluster the percent share of children per district and then manually defined breaks to classify the anthropological dataset.

As demonstrated in Figures 6, 7 and 8, the prevalence rates of overweight and obesity differed markedly between the individual districts. The rates within Vienna show 


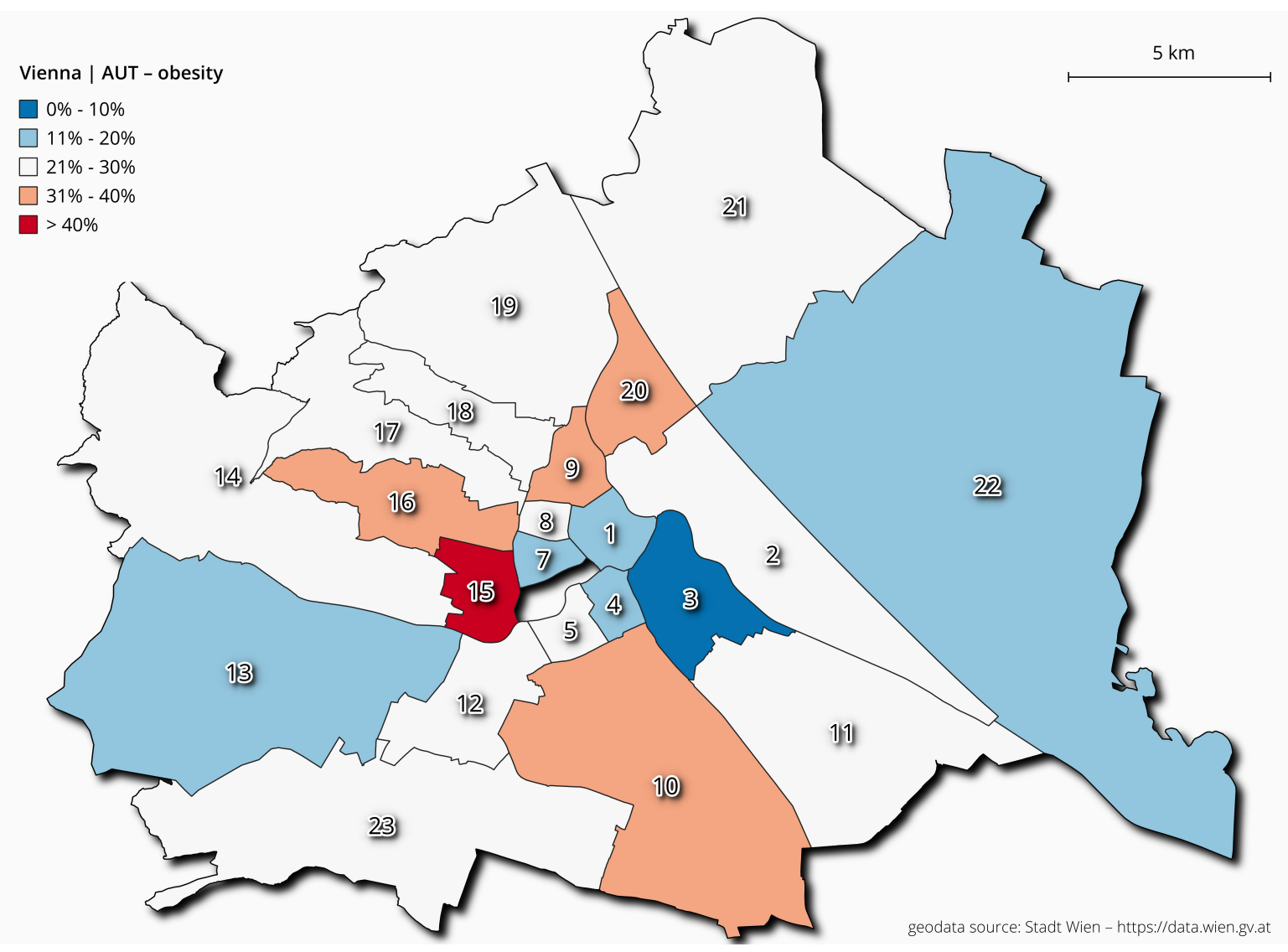

Figure 8 Overweight and obesity rates among 15-year-old adolescents for each Viennese district.

spatial patterns that seem to correlate with the socioeconomic characteristics of the districts. Among six-year-old children, the lowest rates of overweight and obesity $(<10 \%)$ were found in the $1^{\text {st }}, 13^{\text {th }}$ and $19^{\text {th }}$ districts (figure 6). These three districts are the most expensive areas of Vienna and are characterized by a high quality of life, typical of inhabitants with a higher socioeconomic status. In contrast, the highest prevalence $(>30 \%)$ occurred in the $10^{\text {th }}$ and $15^{\text {th }}$ districts, both characterized by a lower socioeconomic status, poorer living conditions and a high rate of inhabitants with a background of migration (Boztepe et al. 2019). At the age of 10 years, the situation became worse for the children (figure 7). With the exception of the $1^{\text {st }}$ district, the prevalence rates of overweight and obesity are above $10 \%$ in all Viennese districts. In the $15^{\text {th }}$ and $10^{\text {th }}$ districts the prevalence rates increased to more than $40 \%$. In six districts the rates were between 30 to $40 \%$. Among the age group 15 years, the $15^{\text {th }}$ district still showed the highest values (Figure $8)$. The analyses clearly show marked spatial distribution patterns of overweight and obesity among Viennese school children. There is no doubt, that urban environments are not homogeneous areas, but we clearly see that distinct differences between individual districts exists. Obesogenic environments are mainly found in distinct districts, characterized by a high proportion of inhabitants with lower educational level, lower socioeconomic status and a higher amount of inhabitants with a background of migration such as the $10^{\text {th }}$ and $15^{\text {th }}$ district in Vienna. 


\section{Conclusion}

Urban centers are not only a place of innovation and economic and cultural diversity; they are also living spaces that harbor a multitude of health risks. From the viewpoint of evolutionary human biology, Homo sapiens is apparently still insufficiently adapted to modern urban life. The 10,000 years of life experience in village communities, the few thousand years in urban habitats, and the few decades of experience in megacities were simply too short to enable adequate adaptation to these environmental conditions. A special problem represents living in an obesogenic environment, typical of today's urban centers and urbanized rural areas. Urbanization or urban lifestyle and increasing rates of overweight and obesity are interwoven. Therefore, both urbanization and obesity are major topics of public health and human biology research.

\section{References}

Statistik Austria (Eds.) (2019). Demographic Yearbook. Wien : Verlag Österreich $\mathrm{GmbH}$.

Aggarwal, B./Jain, V. (2018). Obesity in children: definition, etiology and approach. Indian Journal of Pediatrics 85 (6), 463-471. https://doi.org/10.1007/s12098-0172531-X.

Antiporta, D. A./Smeeth, L./Gilman, R. H./Miranda, J. J. (2016). Length of urban residence and obesity among within-country rural-to-urban Andean migrants. Public Health Nutrition 19 (7), 1270-1278. https://doi.org/10.1017/S1368980015002578.

Antón, S. C./Snodgrass, J. (2012). Origins and evolution of genus homo. Current Anthropology 53 (S6), S479S496. https://doi.org/10.1086/667692.

Armelagos, G. J./Brown, Peter J./Turner, B. (2005). Evolutionary, historical and political economic perspectives on health and disease. Social Science \& Medicine (1982) 61 (4), 755-765. https://doi.org/10.1016/j.socscimed.2004.08.066.
Bachinger, E. (2003). Lebenserwartung und Mortalität in Wien und Österreich - Internationaler Vergleich. Wien : Stadt Wien.

Ball, K./Crawford, D. (2005). Socioeconomic status and weight change in adults: a review. Social Science \& Medicine 60 (9), 1987-2010. https://doi.org/10.1016/j.socscimed.2004.08.056.

Barrett, R./Kuzawa, Ch. W./McDade, T./Armelagos, G. J. (1998). Emerging and re-emerging infectious diseases: The third epidemiologic transition. Annual Review of Anthropology 27 (1), 247-271. https://doi.org/10.1146/annurev.anthro.27.1.247.

Blanco, M. L./Jimenez, M. L./Castellano, H. M. (1992). Urban-rural differences in the growth status of Venezuelan children. American Journal of Human Biology 4 (1), 105-113. https://doi.org/10.1002/ajhb.1310040113.

Blüher, M. (2019). Obesity: global epidemiology and pathogenesis. Nature Reviews Endocrinology 15 (5), 288-298. https://doi.org/10.1038/s41574-019-0176-8.

Bogin, B. (2021). Patterns of Human Growth. Cambridge : Cambridge University Press.

Bork, T./Butsch, C./Kraas, F./Kroll, M. (2009). Megastädte - Neue Risiken für die Gesundheit. Deutsches Ärzteblatt 39 (106), 1877-1881.

Bowlby, J. (1969). Attachment. New York, Basic Books.

Boztepe, K./Hammer, P./König, K. (2019). Migrantinnen und Migranten in Wien 2019. Stadt Wien - Integration und Diversität. Available online at https://www.digital.wienbibliothek.at/wbrup/content/titleinfo/3108775.

Brown, P. J. (1991). Culture and the evolution of obesity. Human Nature 2 (1), 31-57. https://doi.org/10.1007/BF02692180.

Brussaard, J. H./van Erp-Baart, M. A./Brants, H. A./Hulshof, K. F./Löwik, M. R. (2001). Nutrition and health among migrants in The Netherlands. Public Health Nutrition 4 (2B), 659-664. https://doi.org/10.1079/PHN2001149.

Calhoun, J. B. (1962). Population density and social pathology. Scientific American 206, 139-148. https://doi. org/10.1038/scientificamerican0262-139.

Canfield, R. L./Henderson, C. R./Cory-Slechta, D. A./Cox, C./Jusko, T. A./Lanphear, B. P. (2003). Intellectual impairment in children with blood lead concentrations below 10 microg per deciliter. The New England Journal of Medicine 348 (16), 1517-1526. https://doi.org/10.1056/NEJMoa022848.

Carballo, M./Divino, J. J./Zeric, D. (1998). Migration and health in the European Union. Tropical Medicine \& International Health 3 (12), 936-944. https://doi.org/10. 1046/j.1365-3156.1998.00337.x. 
Carson, S. A. (2020). Biological differences between late 19th and early 20th century urban and rural residence 2020. Available online at https://www.cesifo. org/en/publikationen/2020/working-paper/biologicaldifferences-between-late-19th-and-early-20th-century (accessed 4/6/2021).

Caves, R. W. (2005). Encyclopedia of the city. London : Routledge.

Chatterjee, P. (2002). India sees parallel rise in malnutrition and obesity. The Lancet 360 (9349), 1948. https:// doi.org/10.1016/S0140-6736(02)11943-X.

Chiurazzi, M./Cozzolino, M./Orsini, R. C./Di Maro, Martina/Di Minno, M. N. D./Colantuoni, A. (2020). Impact of genetic variations and epigenetic mechanisms on the risk of obesity. International Journal of Molecular Sciences 21 (23). https://doi.org/10.3390/ijms21239035.

Chooi, Y. C./Ding, C./Magkos, F. (2019). The epidemiology of obesity. Metabolism: Clinical and Experimental 92, 6-10. https://doi.org/10.1016/j.metabol.2018.09.005.

Cohen, M. N./Armelagos, G. J./Larsen, C. S. (Eds.) (2013). Paleopathology at the origins of agriculture. Gainesville : University Press of Florida.

Congdon, P. (2019). Obesity and urban environments. International Journal of Environmental Research and Public Health 16 (3). https://doi.org/10.3390/ijerph16030464.

Davis, K. (1955). The origin and growth of urbanization in the world. American Journal of Sociology 60 (5), 429-437. https://doi.org/10.1086/221602.

Dong, Y./Ma, Y./Dong, B./Zou, Z./Hu, P./Wang, Z./Yang, Y./Song, Y./Ma, J. (2019). Geographical variation and urban-rural disparity of overweight and obesity in Chinese school-aged children between 2010 and 2014: two successive national cross-sectional surveys. BMJ Open 9 (4), e025559. https://doi.org/10.1136/bmjopen-2018-025559.

Duignan, B. (2019). Encyclopædia Britannica. Chicago : Encyclopædia Britannica Inc.

Dunbar, R. I. M. (1993). Coevolution of neocortical size, group size and language in humans. Behavioral and Brain Sciences 16 (4), 681-694. https://doi.org/10.1017/S0140525X00032325.

Eaton, S. B./Konner, M. (1985). Paleolithic nutrition. A consideration of its nature and current implications. The New England Journal of Medicine 312 (5), 283-289. https://doi.org/10.1056/NEJM198501313120505.

Ebbeling, C. B./Pawlak, D. B./Ludwig, D. S. (2002). Childhood obesity: public-health crisis, common sense cure. The Lancet 360 (9331), 473-482. Available online at https://www.academia.edu/2318105/Childhood_obesity_public_health_crisis_common_sense_cure.
Ebrahim, S./Kinra, S./Bowen, L./Andersen, E./BenShlomo, Y./Lyngdoh, T./Ramakrishnan, L./Ahuja, R. C./Joshi, P./Das, S. M./Mohan, M./Smith, G. D./Prabhakaran, D./Reddy, K. S. (2011). Correction: The Effect of rural-to-urban migration on obesity and diabetes in India: A cross-sectional study. PLoS Medicine 8 (5). https://doi.org/10.1371/annotation/b1ecad56-652a-4a309920-26679d5a584a.

FAO (2008). The state of food insecurity in the world. Roma 2008.

Faskunger, J./Eriksson, U./Johansson, S.-E./Sundquist, K./Sundquist, J. (2009). Risk of obesity in immigrants compared with Swedes in two deprived neighbourhoods. BMC public health 9, 304. https://doi.org/10.1186/14712458-9-304.

Florentino, R. F. (2002). The burden of obesity in Asia: Challenges in assessment, prevention and management. Asia Pacific Journal of Clinical Nutrition 11, S676-S680. https://doi.org/10.1046/j.1440-6047.11.s8.4.x.

Ford, E. S./Mokdad, A. H. (2008). Epidemiology of obesity in the western hemisphere. The Journal of Clinical Endocrinology and Metabolism 93 (11 Suppl 1), S1-8. https://doi.org/10.1210/jc.2008-1356.

Gnavi, R./Spagnoli, T. D./Galotto, C./Pugliese, E./Carta, A./Cesari, L. (2000). Socioeconomic status, overweight and obesity in prepuberal children: a study in an area of Northern Italy. European Journal of Epidemiology 16 (9), 797-803. https://doi.org/10.1023/A:1007645703292.

Griffin, E. (2018). Diets, hunger and living standards during the british industrial revolution. Past \& Present 239 (1), 71-111. https://doi.org/10.1093/pastj/gtx061.

Groeneveld, I. F./Solomons, N. W./Doak, C. M. (2007). Nutritional status of urban schoolchildren of high and low socioeconomic status in Quetzaltenango, Guatemala. Revista Panamericana de Salud Publica Pan American Journal of Public Health 22 (3), 169-177. https://doi.org/10.1590/s1020-49892007000800003.

Gushulak, B. D./MacPherson, D. W. (2006). The basic principles of migration health: population mobility and gaps in disease prevalence. Emerging Themes in Epidemiology 3, 3. https://doi.org/10.1186/1742-7622-3-

Haas, J. S./Lee, L. B./Kaplan, C. P./Sonneborn, D./Phillips, K. A./Liang, S.-Y. (2003). The association of race, socioeconomic status, and health insurance status with the prevalence of overweight among children and adolescents. American Journal of Public Health 93 (12), 2105-2110. https://doi.org/10.2105/ajph.93.12.2105.

Han, J. C./Lawlor, D. A./Kimm, S. Y. S. (2010). Childhood obesity. The Lancet 375 (9727), 1737-1748. https:// doi.org/10.1016/S0140-6736(10)60171-7. 
Haslam, D. (2007). Obesity: a medical history. Obesity Reviews 8 Suppl 1, 31-36. https://doi.org/10.1111/j.1467789X.2007.00314.X.

Hook, J. van/Balistreri, K. S. (2007). Immigrant generation, socioeconomic status, and economic development of countries of origin: a longitudinal study of body mass index among children. Social Science \& Medicine 65 (5), 976-989. https://doi.org/10.1016/j.socscimed.2007.04.032.

Hossain, P./Kawar, B./El Nahas, M. (2007). Obesity and diabetes in the developing world-a growing challenge. The New England Journal of Medicine 356 (3), 213-215. https://doi.org/10.1056/NEJMp068177.

$\mathrm{Hu}$, Yan/Lin, Weiqun/Tan, Xuying/Liu, Yu/Wen, Yuqi/Xing, Yanfei/Ma, Ying/Liu, Huiyan/Song, Yanyan/Liang, Jingjing/Lam, Kin Bong Hubert/Lin, Suifang (2020). Trends in urban/rural inequalities in physical growth among Chinese children over three decades of urbanization in Guangzhou: 1985-2015. BMC Public Health 20 (1), 1190. https://doi.org/10.1186/ s12889-020-09239-7.

Jaffar, S. T. A./Chen, L.-Z./Younas, H./Ahmad, N. (2017). Heavy metals pollution assessment in correlation with magnetic susceptibility in topsoils of Shanghai. Environmental Earth Sciences 76 (7). https://doi.org/10.1007/ s12665-017-6598-5.

Jenks, G. F./Caspall, F. C. (1971). Error on choroplethic maps: Definition, measurement, reduction. Annals of the Association of American Geographers 61 (2), 217-244. https://doi.org/10.1111/j.1467-8306.1971. tb00779.x.

Kaplan, M. S./Huguet, N./Newsom, J. T./McFarland, B. H. (2004). The association between length of residence and obesity among Hispanic immigrants. American Journal of Preventive Medicine 27 (4), 323-326. https://doi.org/10.1016/j.amepre.2004.07.005.

Kaupová, S./Brůzek, J./Velemínský, P./Cerníková, A. (2013). Urban-rural differences in stature in the population of medieval Bohemia. Anthropologischer Anzeiger 70 (1), 43-55. https://doi.org/10.1127/0003-5548/2012/ 0276.

Khan, M. M. H./Kraemer, A. (2014). Are rural-urban migrants living in urban slums more vulnerable in terms of housing, health knowledge, smoking, mental health and general health? International Journal of Social Welfare 23 (4), 373-383. https://doi.org/10.1111/ijsw.12053.

Kilaf, E./Kirchengast, S. (2011). Socio-economic position and obesity among Turkish migrant women in Vienna, Austria. Journal of Life Sciences 3 (2), 107-116. https://doi.org/10.1080/09751270.2011.11885177.

Kimm, S. Y. S./Obarzanek, E. (2002). Childhood obesity: a new pandemic of the new millennium. Pediatrics 110 (5), 1003-1007. https://doi.org/10.1542/peds.110.5.1003.
Kirchengast, S./Hagmann, D. (2021). Spatial disparity in the prevalence of childhood obesity in Vienna. 2021: in prep.

Kirchengast, S./Schober, E. (2006). To be an immigrant: a risk factor for developing overweight and obesity during childhood and adolescence? Journal of Biosocial Science 38 (5), 695-705. https://doi.org/10.1017/S0021932005027094.

Kirchengast, S./Singh, M./Kilaf, E. (2012). Obesity prevalence and socioeconomic position among two different groups of immigrant women in Vienna, Austria. In: M. P. Martinez/H. Robinson (Eds.). Obesity and Weight Management: Challenges, Practices and Health Implications. NOVA Publisher, 71-92.

Komlos, J. (1986). Patterns of children's growth in east-central Europe in the eighteenth century. Annals of Human Biology 13 (1), 33-48. https://doi.org/10.1080/03014468600008181.

Komlos, J. (Ed.) (1994). Stature, living standards, and economic development: Essays in Anthropometric History. Chicago : Univ. of Chicago Press.

Komlos, J. (Ed.) (1998). The biological standard of living in comparative perspective: Contributions to the conference held in Munich January 18-22, 1997, for the XIIth Congress of the International Economic History Association. Stuttgart : Steiner.

Kromeyer-Hausschild, K./Wabitsch, M./Kunze, D./Geller, F./Geiß, H. C./Hesse, V./von Hippel, A./Jäger, U./Korte, W./Menner, K./Müller, G./Müller, J. M./Niemann-Pilatus, A./Remer, T./Schäfer, F./Wittchen, H. U./Zabransky, S./Zellner, K./Ziegler, A./Hebebrand, J. (2001). Perzentile für den Bodymass Index für das Kindes- und Jugendalter unter Heranziehung verschiedener deutscher Stichproben. Monatsschrift Kinderheilkunde (149), 807-818.

Lasserre, A. M./Chiolero, A./Paccaud, F./Bovet, P. (2007). Worldwide trends in childhood obesity. Swiss Medical Weekly 137 (9-10), 157-158.

Leon, D. A. (2008). Cities, urbanization and health. International Journal of Epidemiology 37 (1), 4-8. https://doi.org/10.1093/ije/dym271.

Lieberman, L. S. (2006). Evolutionary and anthropological perspectives on optimal foraging in obesogenic environments. Appetite 47 (1), 3-9. https://doi.org/10.1016/j.appet.2006.02.011.

Lissner, L./Wijnhoven, T. M. A./Mehlig, K./Sjöberg, A./Kunesova, M./Yngve, A./Petrauskiene, A./Duleva, V./Rito, A. I./Breda, J. (2016). Socioeconomic inequalities in childhood overweight: heterogeneity across five countries in the WHO European Childhood Obesity Surveillance Initiative (COSI-2008). International Journal of Obesity 40 (5), 796-802. https://doi.org/10.1038/ijo.2016.12. 
Logan, A. C./Jacka, F. N. (2014). Nutritional psychiatry research: an emerging discipline and its intersection with global urbanization, environmental challenges and the evolutionary mismatch. Journal of Physiological Anthropology 33, 22. https://doi.org/10.1186/1880-680533-22.

Mahase, E. (2019). Obesity rates are increasing more rapidly in rural areas than in cities. BMJ 365, 12088. https://doi.org/10.1136/bmj.12088.

Maher, L. A./Richter, T./Macdonald, D./Jones, M. D./Martin, L./Stock, J. T. (2012). Twenty thousand-year-old huts at a hunter-gatherer settlement in eastern Jordan. PloS One 7 (2), e31447. https://doi.org/10.1371/journal.pone.0031447.

Martínez-Carrión, J.-M./Moreno-Lázaro, J. (2007). Was there an urban height penalty in Spain, 1840-1913? Economics and Human Biology 5 (1), 144-164. https://doi.org/10.1016/j.ehb.2006.09.001.

Matthews, C. M. (2012). Exploring the obesity epidemic. Proceedings (Baylor University. Medical Center) 25 (3), 276-277. https://doi.org/10.1080/08998280.2012.11928848.

McGee, D. L. (2005). Body mass index and mortality: a meta-analysis based on person-level data from twentysix observational studies. Annals of Epidemiology 15 (2), 87-97. https://doi.org/10.1016/j.annepidem.2004.05.012.

Miller, G. (2016). Roots of the urban mind. Science 352 (6288), 908-911. https://doi.org/10.1126/science.352.6288.908.

Misra, A./Ganda, O. P. (2007). Migration and its impact on adiposity and type 2 diabetes. Nutrition 23 (9), 696-708. https://doi.org/10.1016/j.nut.2007.06.008.

Mou, J./Griffiths, S. M./Fong, H./Dawes, M. G. (2013). Health of China's rural-urban migrants and their families: a review of literature from 2000 to 2012. British Medical Bulletin 106, 19-43. https://doi.org/10.1093/bmb/ldt016.

Mumford, L. (1961). The city in history: Its origins, its transformations, and its prospects. San Diego and New York and London, Harcourt Inc.

Must, A./Jacques, P. F./Dallal, G. E./Bajema, C. J./Dietz, W. H. (1992). Long-term morbidity and mortality of overweight adolescents. A follow-up of the Harvard Growth Study of 1922 to 1935. The New England Journal of Medicine 327 (19), 1350-1355. https://doi.org/10.1056/NEJM199211053271904.

Najera, H./Nandy, S./Carrillo-Larco, R. M./Miranda, J. J. (2019). Within-country migration and obesity dynamics: analysis of 94,783 women from the Peruvian demographic and health surveys. BMC public health 19 (1), 263. https://doi.org/10.1186/s12889-019-6586-7.
NCD Risk Factor Collaboration (2019). Rising rural body-mass index is the main driver of the global obesity epidemic in adults. Nature 569 (7755), 260-264. https:// doi.org/10.1038/s41586-019-1171-x.

Neiderud, C.-J. (2015). How urbanization affects the epidemiology of emerging infectious diseases. Infection Ecology \& Epidemiology 5, 27060. https://doi.org/10.3402/iee.v5.27060.

Nurwanti, E./Hadi, H./Chang, J.-S./Chao, J. C.J./Paramashanti, B. A./Gittelsohn, J./Bai, C.-H. (2019). Rural-urban differences in dietary Behavior and obesity: Results of the Riskesdas study in 10-18-year-old indonesian children and adolescents. Nutrients 11 (11). https://doi.org/10.3390/nu11112813.

Ogden, C. L./Fryar, C. D./Hales, C. M./Carroll, M. D./Aoki, Y./Freedman, D. S. (2018). Differences in obesity prevalence by demographics and urbanization in US children and adolescents, 2013-2016. JAMA 319 (23), 2410-2418. https://doi.org/10.1001/jama.2018.5158.

Paciorek, C. J./Stevens, G. A./Finucane, M. M./Ezzati, M. (2013). Children's height and weight in rural and urban populations in low-income and middle-income countries: a systematic analysis of population-representative data. The Lancet Global Health 1 (5), e300-e309. https:// doi.org/10.1016/S2214-109X(13)70109-8.

Pijl, H. (2011). Obesity: evolution of a symptom of affluence. The Netherlands Journal of Medicine 69 (4), 159-166.

Pollard, T. M. (2008). Western diseases: An evolutionary perspective. Cambridge : Cambridge University Press.

Popkin, B. M. (2001). The nutrition transition and obesity in the developing world. The Journal of Nutrition 131 (3), 871S-873S. https://doi.org/10.1093/jn/131.3.871S.

Popkin, B. M. (2003). The nutrition transition in the developing world. Development Policy Review 21 (5-6), 581-597. https://doi.org/10.1111/j.1467-8659.2003.00225. $\mathrm{x}$.

Popkin, B. M./Gordon-Larsen, P. (2004). The nutrition transition: worldwide obesity dynamics and their determinants. International Journal of Obesity and related Metabolic Disorders 28 Suppl 3, S2-9. https://doi.org/10.1038/sj.ijo.0802804.

Popkin, B. M./Udry, J. R. (1998). Adolescent obesity increases significantly in second and third generation U.S. immigrants: the national longitudinal study of adolescent health. The Journal of Nutrition 128 (4), 701-706. https://doi.org/10.1093/jn/128.4.701.

Poston, W. S. C./Foreyt, J. P. (1999). Obesity is an environmental issue. Atherosclerosis 146 (2), 201-209. https://doi.org/10.1016/s0021-9150(99)00258-0. 
Poulsen, P. H./Biering, K./Winding, T. N./Nohr, E. A./Andersen, J. H. (2018). How does childhood socioeconomic position affect overweight and obesity in adolescence and early adulthood: a longitudinal study. BMC obesity 5, 34. https://doi.org/10.1186/s40608-018-0210-8.

Qian, Z./Zhang, J./Wei, F./Wilson, W. E./Chapman, R. S. (2001). Long-term ambient air pollution levels in four Chinese cities: inter-city and intra-city concentration gradients for epidemiological studies. Journal of exposure analysis and environmental epidemiology 11 (5), 341-351. https://doi.org/10.1038/sj.jea.7500170.

Rami, B./Schober, E./Kirchengast, S./Waldhör, T./Sefranek, R. (2004). Prevalence of overweight and obesity in male adolescents in Austria between 1985 and 2000. A population based study. Journal of Pediatric Endocrinology \& Metabolism 17 (1), 67-72. https://doi.org/10.1515/jpem.2004.17.1.67.

Ramsden, E. (2009). The urban animal: population density and social pathology in rodents and humans. Bulletin of the World Health Organization 87 (2), 82. https://doi.org/10.2471/BLT.09.062836.

Roberts, C. A. (2016). Palaeopathology and its relevance to understanding health and disease today: the impact of the environment on health, past and present. Anthropological Review 79 (1), 1-16. https://doi.org/10.1515/ anre-2016-0001.

Roberts, C. A./Lewis, M. E. (2002). Ecology and infectious disease in Britain from prehistory to the present: The Case of Respiratory infections. Biennial Books of EEA (2), 179-192.

Rona, R. J. (2000). The impact of the environment on height in Europe: conceptual and theoretical considerations. Annals of human biology 27 (2), 111-126. https://doi.org/10.1080/030144600282235.

Scheidl, W. (2010). Disease and death in the ancient city of Rome. In: P. Erdkamp (Ed.). The Companion to Ancient Rome. Cambridge University Press.

Schell, L. M. (2010). Industrial polluntants and human evolution. In: M. P. Mühlenheim (Ed.). Human Evolutionary Biology. Cambridge University Press, 566-580.

Schell, L. M. (2014). Culture, urbanism and changing human biology. Global Bioethics Problemi di bioetica 25 (2), 147-154. https://doi.org/10.1080/11287462.2014.897070.

Schell, L. M./Gallo, M. V./Ravenscroft, J. (2009). Environmental influences on human growth and development: historical review and case study of contemporary influences. Annals of human biology 36 (5), 459-477. https://doi.org/10.1080/03014460903067159.

Schonfield, R./Reher, D./Bideau, A. (1991). The decline of mortality in Europe. Oxford, Clarendon Press Oxford.
Schott, D. (2014). Europäische Urbanisierung (1000 - 2000): Eine umwelthistorische Einführung. Köln, Böhlau.

Shekar, M./Popkin, B. (Eds.) (2020). Obesity: Health and economic consequences of an impending global challenge. Washington, DC.

Shen, C./Zhou, Z./Lai, S./Tao, X./Zhao, D./Dong, W./Li, D./Lan, X./Gao, J. (2019). Urban-rural-specific trend in prevalence of general and central obesity, and association with hypertension in Chinese adults, aged 18-65 years. BMC public health 19 (1), 661. https://doi.org/10. 1186/s12889-019-7018-4.

Smith, M. J. de/Goodchild, M. F./Longley, P. (2020). Geospatial analysis: A comprehensive guide to principles, techniques and software tools. 6th ed. Leicester, Matador.

Spinelli, A./Buoncristiano, M./Kovacs, V. A./Yngve, A./Spiroski, I./Obreja, G./Starc, G./Pérez, N./Rito, A. I./Kunešová, M./Sant'Angelo, V. F./Meisfjord, J./Bergh, I. H./Kelleher, C./Yardim, N./Pudule, I./Petrauskiene, A./Duleva, V./Sjöberg, A./Gualtieri, A./Hassapidou, M./Hyska, J./Burazeri, G./Petrescu, C. H./Heinen, M./Takacs, H./Zamrazilová, H./Bosi, T. B./Sacchini, E./Pagkalos, I./Cucu, A./Nardone, P./Gately, P./Williams, J./Breda, J. (2019). Prevalence of severe obesity among primary school children in 21 european countries. Obesity facts 12 (2), 244-258. https://doi.org/10.1159/000500436.

Stadt Wien (2011). Bezirksgrenzen Wien: Bezirksgrenzen, Wien Politische Landesgrenze und Bezirksgrenzen von Wien 2011. Available online at https://www. data.gv.at/katalog/dataset/86c29af5-c52c-423d-876482c1bb037936.

Stadt Wien (2012). Landesgrenze Wien: Politische Landesgrenze von Wien 2012. Available online at https://www.spatialanalysisonline.com/HTML/index.html?classification_and_clustering.htm.

Stringer, C. (2016). The origin and evolution of Homo sapiens. Philosophical transactions of the Royal Society of London. Series B, Biological sciences 371 (1698). https://doi.org/10.1098/rstb.2015.0237.

Swinburn, B./Egger, G./Raza, F. (1999). Dissecting obesogenic environments: the development and application of a framework for identifying and prioritizing environmental interventions for obesity. Preventive medicine 29 (6 Pt 1), 563-570. https://doi.org/10.1006/pmed.1999.0585.

Tanner, J. M./Eveleth, P. B. (1976). Urbanization and growth. In: G.B. Harrison/J. B. Gibson (Eds.). Man in Urban Environments. Oxford, Clarendon OPress, 144-166.

Thaker, V. V. (2017). Genetic and epigenetic causes of obesity. Adolescent Medicine 28 (2), 379-405. 
Timmermans, J./Dijkstra, C./Kamphuis, C./Huitink, M./Zee, E. van der/Poelman, M. (2018). 'Obesogenic' school food environments? An urban case study in The Netherlands. International journal of environmental research and public health 15 (4). https://doi.org/10.3390/ijerph15040619.

Ulijaszek, S. J. (2007). Obesity: a disorder of convenience. Obesity Reviews 8 Suppl 1, 183-187. https://doi.org/10. 1111/j.1467-789X.2007.00339.x.

Ulijaszek, S. J./Lofink, H. (2006). Obesity in biocultural perspective // Obesity in Biocultural Perspective. Annual Review of Anthropology 35 (1), 337-360. https://doi.org/10.1146/annurev.anthro.35.081705.123301.

United Nations (Ed.) (2015). World Urbanization Prospects: The 2014 Revision. Department of Economic and Social Affairs, Population Division. ST/ESA/SER.A/366. Available online at https://www.un. org/en/development/desa/publications/2014-revisionworld-urbanization-prospects.html (accessed 4/6/2021).

Vlahov, D./Freudenberg, N./Proietti, F./Ompad, D./Quinn, A./Nandi, V./Galea, S. (2007). Urban as a determinant of health. Journal of Urban Health 84 (3 Suppl), i16-26. https://doi.org/10.1007/s11524-007-91693.

Wang, Y. C./McPherson, K./Marsh, T./Gortmaker, S. L./Brown, M. (2011). Health and economic burden of the projected obesity trends in the USA and the UK. The Lancet 378 (9793), 815-825. https://doi.org/10.1016/ S0140-6736(11)60814-3.

Wang, Y./Beydoun, M. A. (2007). The obesity epidemic in the United States-gender, age, socioeconomic, racial/ethnic, and geographic characteristics: a systematic review and meta-regression analysis. Epidemiologic reviews 29, 6-28. https://doi.org/10.1093/epirev/mxm007.

Wang, Y./Lobstein, T. (2006). Worldwide trends in childhood overweight and obesity. International Journal of Pediatric Obesity 1 (1), 11-25. https://doi.org/10.1080/17477160600586747.

WHO (2000). Obesity: preventing and managing the global epidemic. Geneva, WHO.

WHO (2010). World Health Organization Global Database on Body mass index. Geneva, WHO.

WHO (2020). World Health Organization. Obesity and Overweight. Geneva, WHO.

Wilkinson, T. J./Philip, G./Bradbury, J./Dunford, R./Donoghue, D./Galiatsatos, N./Lawrence, D./Ricci, A./Smith, S. L. (2014). Contextualizing early urbanization. Settlement cores, early states and agro-pastoral strategies in the fertile crescent during the fourth and third millennia BC. Journal of World Prehistory 27 (1), 43-109. https://doi.org/10.1007/s10963-014-9072-2.
Withrow, D./Alter, D. A. (2011). The economic burden of obesity worldwide: a systematic review of the direct costs of obesity. Obesity Reviews 12 (2), 131-141. https:// doi.org/10.1111/j.1467-789X.2009.00712.x.

Wolin, K. Y./Colangelo, L. A./Chiu, B. C.-H./Gapstur, S. M. (2009). Obesity and immigration among Latina women. Journal of immigrant and minority health 11 (5), 428-431. https://doi.org/10.1007/s10903-007-9115-1.

Zehetmayer, M. (2013). Health, market integration, and the urban height penalty in the US, 1847-1894. Cliometrica 7 (2), 161-187. https://doi.org/10.1007/ s11698-012-0085-8.

Zong, X./Li, H./Zhang, Y.-Q./Wu, H. (2017). Narrowing urban-suburban rural disparities in physical growth among children in China: findings from the 5th national survey in 2015. Annals of human biology 44 (7), 636-641. https://doi.org/10.1080/03014460.2017.1358394. 